\title{
Swearword Translation in Steve Jobs: A Communicative/Semantic Perspective
}

\author{
Licheng $\mathrm{Lu}^{1} \&$ Aifen $\mathrm{Li}^{1}$ \\ ${ }^{1}$ Faculty of English Language and Culture, Guangdong University of Foreign Studies, Guangzhou, China \\ Correspondence: Licheng Lu, Faculty of English Language and Culture, Guangdong University of Foreign \\ Studies, No. 2 Baiyun Dadao Bei, Guangzhou, China. E-mail: lulicheng@gdufs.edu.cn
}

Received: January 2, 2020 Accepted: January 31, 2020 Online Published: February 10, 2020

doi:10.5539/ells.v10n1p46 URL: https://doi.org/10.5539/ells.v10n1p46

\begin{abstract}
Swearwords are commonly used in daily communications, but how to translate swearwords appropriately has received relatively little attention. This research explores swearword translation from English into Chinese based on Peter Newmark's theory of communicative and semantic translation through a case study of the book Steve Jobs. Through detailed analyses, it is proved that translating swearwords should be reader-oriented so that the translations can produce an equivalent effect on the target readers. It is also found that many elements should be considered in swearword translation, such as character of swearer, context, source language and culture as well as target language and culture.
\end{abstract}

Keywords: swearword, translation, Steve Jobs, Peter Newmark

\section{Introduction}

Translation, as the essential tool in the communication between different languages and cultures, should cover every aspect of life, whether noble or low, decent or vulgar. However, academic studies have so far seldom touched upon the translation of dialogue, especially the low or vulgar aspect such as swearwords.

Swearword translation is a dilemma for translators, for swearwords are often regarded as indecent and inappropriate for readers, especially teenage and children readers. Whether to translate them and how to translate them still remain controversial. The lack of sophisticated or comprehensive studies into swearword translation hinders people's understanding of swearwords in different languages and cultures, and intercultural communications at large.

In view of this situation, this research conducts a case study of swearword translation in the popular book Steve Jobs from the perspective of Peter Newmark's communicative and semantic translation theory, hoping to provide readers with some knowledge of whether and how to translate swearwords from English into Chinese.

\section{Literature Review}

Oxford Dictionary defines SWEARWORD as "rude or offensive language used especially when angry". Swearwords date back to a long time ago when human beings began to express feelings or emotions through language. However, they are often regarded as embarrassing because they are likely to bring about negative responses on the part of the listeners. There have been many protests or banning on the use of swearwords in public places, such as TV, broadcasting or movies, yet swearing is an indispensable part of everybody's life. "No people have ever abandoned its habits of swearing merely because the State... forbad it" (Wajnryb, 2004, p. 5).

Ruth Wajnryb (2004) divided swearwords into two kinds, the words constituting swearing and the words referring to swearing. In order to make it clearer, he further divided swearing into smaller segments, like abusive swearing, blasphemy, cursing, cussing, dysphemism, epithet, euphemistic swearing, expletive, foul language, insult, invective, oath, obscenity, profanity, swear, taboo words, and vulgarity.

Ashley Montagu (2001) also illustrated how swearing came into being. As an infant, the way to express his deprivations or frustrations is howling, and later crying. After he has entered adolescence, he tends to use the "manly form of conduct"- swearing. That is to say, swearing is a human instinct. It is also an "outlet for aggressive feelings thus induced to "restore the normal psychophysical equilibrium of the individual" (Montagu, 2001, p. 72). Based on a detailed analysis of the functions of swearing, she concluded that swearing serves as a 
relief mechanism whereby excess energy is allowed to escape without doing anyone serious injury, while doing the swearer some good.

With the liberalization of society as well as of literature, swearwords are frequently used in literary works. However, scholars' views on such a trend vary. Some argue against the popular use of swearwords in literature because literature, as processed and regulated language, reflects the value and attitude of the author and thus authors should take up the social responsibility to make sure that their works do not cast a negative effect on readers, especially on teenage or children readers (Huang, 2009). If swearwords are to be used, they should be used appropriately, otherwise, they would lower the value of such work, and more importantly, pollute the cultural environment (Ma, 1996). Some tactics can be applied to deal with swearwords, such as replacing them with symbols like " $X$ " or "......" in Chinese, which will represent the swearwords but in a more indirect or decent way (Wu, 1987).

Others insist that swearing is a way to relieve one's emotions or feelings, through a look into which, the person's emotions or feelings, like anger, surprise, or frustration, can thus be understood. Sometimes, swearwords do not just reflect what a person is, but more significantly, what a society or a culture is. They serve as an epitome of people's life as well as spirit (Chen, 2011). As strong emotional words, swearwords play an important role in literary works. Whether said by the narrator as in the case of The Catcher in the Rye, or by the character as in the case of Steve Jobs, swearwords create a full personality of the swearer. Through these words, readers can have a better or more complete idea of the personality of the character or further the theme of the literary work.

Though swearwords play such a significant part, discussions on translation of swearwords generally fall into two major groups. Some argue that it is better to translate swearwords literally in order to preserve the original flavor and cultural concept, which will in turn help promote the communication between two languages and cultures as target readers can, through reading the translations, know more about the swearwords and the cultural indications behind them, ultimately a deeper understanding of the source language and culture (Gu, 2010). Others hold the opinion that swearwords should be translated in a way to reproduce their communicative effects on the target readers. The translator should try to make the translations as natural as possible to achieve functional equivalence (Golan, 2006).

However, previous researches were mainly conducted on swearwords as a whole or specifically on swearwords in movie subtitles. No research ever investigated into the translation of swearwords in biographies. Moreover, there was a lack of well-grounded theoretical foundations. The categorizations of swearwords did not have a clear-cut line. The specific translation approach to be applied to a specific type of swearwords is yet to be found.

\section{Theoretical Framework}

Whenever there is translation, there are heated debates over whether to translate literally or freely, or whether to adopt a reader-oriented or author-oriented approach. The gap between emphasis on source and on target language is finally narrowed due to the appearance of communicative and semantic translation theory.

In Approaches to Translation, Peter Newmark (2001) introduced the concept of communicative and semantic translation. Communicative translation "attempts to produce on its readers an effect as close as possible to that obtained on the readers of the original" while semantic translation "attempts to render, as closely as the semantic and syntactic structures of the second language allow, the exact contextual meaning of the original" (Newmark, 2001, p. 39).

These two methods are widely different. Communicative translation focuses on target readers, who want to read the translated work without any difficulty or obscurity and thus expect the translation to be like a native work in language as well as in culture while semantic translation emphasizes more on the original. Generally, communicative translation tends to be "smoother, simpler, clearer, more direct, more conventional" while semantic translation is likely to be "more complex, more awkward, more detailed, more concentrated" (Newmark, 2001, p. 38).

In light of the communicative approach, the translator has the freedom "to correct or improve the logic; to replace clumsy with elegant, or at least functional, syntactic structures; to remove obscurities; to eliminate repetition and tautology; to exclude the less likely interpretations of an ambiguity; to modify and clarify jargon" or to "normalize bizarreries of idiolect" (Newmark, 2001, p. 42). In contrast, in semantic translation, the translator is trying to preserve the original flavor and tone.

Peter Newmark related his translation methods to the text functions: expressive, informative and vocative. Expressive text focuses on the mind of the speaker, the writer, the originator of the utterance, informative function on external situation, the facts of a topic, reality outside language, including reported ideas or theories 
and vocative function on the readership, i.e., the addressee (Hoffman, 1996, p. 140). In fact, every single text must perform the three functions together, but will have one function in domination. According to Newmark, semantic translation guarantees the expressive function while communicative translation caters to the informative and vocative functions (Newmark, 2001, p. 47).

\section{Swearword Translation in Steve Jobs}

In biographies, the expressive function stands out. But what text function do swearwords emphasize, expressive, informative or vocative? Which approach should be applied to swearword translation in biographies, semantic translation or communicative translation? This section presents a detailed analysis of the translation of swearwords from English to Chinese in the biography Steve Jobs to find answers to the above questions.

\subsection{Introduction to Steve Jobs}

Steve Jobs is the authorized biography of Steve Jobs, designer, inventor, and chief executive officer of Apple Inc., written at the request of Jobs by the acclaimed biographer Walter Isaacson, a former executive at CNN and Times who has written best-selling biographies about Benjamin Franklin and Albert Einstein.

Based on more than forty interviews with Jobs conducted over two years, in addition to interviews with more than one hundred family members, friends, adversaries, competitors, and colleagues, Isaacson was given "exclusive and unprecedented" access to Jobs's life. Jobs was said to have encouraged the people interviewed to speak honestly. He asked for no control over its content other than the book's cover, and waived the right to read it before it was published.

Originally planned for release on March 6, 2012, the release date was moved forward to October 24, 2011 due to his death on October 5, 2011. The translated Chinese version was done by Yu Qian, Guan Yanqi, Wei Qun, Zhao Mengmeng and Tang Song from mainland China.

\subsection{Swearwords in Steve Jobs}

Swearwords, as emotional intensifiers, show feelings or emotions of the speakers or swearers. In Steve Jobs, there are a lot of swearwords. The majority were said by Jobs himself. When he felt upset, annoyed, dissatisfied, depressed, or angry, he tended to swear. These swearwords also reveal his characteristics as a straightforward and emotional perfectionist. A summary is given below on the sources, distributions and functions of swearwords in this book.

Table 1. Swearwords in Steve Jobs

\begin{tabular}{lll}
\hline Subject & Distribution Frequency & Total \\
\hline Religion or God & God 7; hell 4; Christ 1; Jesus 1; Jesus Christ 1; Judas 1; damn 4; goddamn 1; dammit 3 & 23 \\
Organs or Sexuality & Fuck 20; fucking 11; asshole 8; assaholic 1; dick 3 & 43 \\
Female & Bitch 1; whore 3; slut 1 & 5 \\
Animal & Ass 8 & 8 \\
Excrement & Shit 36; shitty 4; shithead 5; bullshit 9; crap 17 & 71 \\
Others & Piss 10; bozo 12; suck 10; nut 4; nutcase 1; jerk 3; buffoon 1; screw 7 & 48 \\
\hline
\end{tabular}

From Table 1, it is found that swearwords related to excrement constitute the largest part in this book with SHIT being the most frequent one.

\subsection{Swearword Translation in Steve Jobs}

Halliday (2007) claimed that different language structures will perform different functions such as ideational meta-function, interpersonal meta-function and textual meta-function, and thus cast different effects on target readers, which will in turn require different translation methods. Accordingly, this research categorizes swearwords in Steve Jobs into four types: independent pattern, reference pattern, insertion pattern and replacement pattern with different sentence structures, functions, effects, and explains the appropriate translation methods for each category.

\subsubsection{Independent Pattern}

Independent pattern refers to the swearwords that make up an independent or separate part in a sentence by themselves, such as "Bullshit", "Fuck", often with an exclamation mark at the end. 
Table 2. Independent-patterned swearwords in Steve Jobs

\begin{tabular}{|c|c|c|c|c|c|}
\hline Order & Swearword & Subject & Swearer & Chapter \& Context & Translation \\
\hline 1 & 'It's real. Holy shit, it's real.' & $\begin{array}{l}\text { Religion \& } \\
\text { excrement }\end{array}$ & Steve \& Woz & $\begin{array}{l}\text { 【2】 After great effort, they } \\
\text { found the journal about how to } \\
\text { make long distance call for free }\end{array}$ & $\begin{array}{l}\text { 这是真的, 天哪, 这 } \\
\text { 是真的 }\end{array}$ \\
\hline 2 & $\begin{array}{l}\text { Holy Christ, this guy is going } \\
\text { to be something else }\end{array}$ & $\begin{array}{l}\text { Religion or } \\
\text { god }\end{array}$ & Frank Burge & $\begin{array}{l}\text { 【6】 He saw all the things in } \\
\text { Jobs' garage. }\end{array}$ & $\begin{array}{l}\text { 天哪, 这个人肯定是 } \\
\text { 个怪胎 }\end{array}$ \\
\hline 3 & $\begin{array}{l}\text { Dammit, Steve, I asked you } \\
\text { point-blank about these shares } \\
\text { and you denied it was you. }\end{array}$ & $\begin{array}{l}\text { Religion or } \\
\text { god }\end{array}$ & Amelio & $\begin{array}{l}\text { 【24】 He did not expect that } \\
\text { Steve sold the shares. }\end{array}$ & $\begin{array}{l}\text { 该死, 史蒂夫, 我直 } \\
\text { 接问过你, 你说不是 } \\
\text { 你 }\end{array}$ \\
\hline 4 & $\begin{array}{l}\text { "Fuck you," replied Lasseter, } \\
\text { who did not normally use such } \\
\text { language. }\end{array}$ & $\begin{array}{l}\text { Organs or } \\
\text { sexuality }\end{array}$ & Lasseter & $\begin{array}{l}\text { 【32】 He found out that he was } \\
\text { cheated by his friend and trapped } \\
\text { the company in trouble }\end{array}$ & $\begin{array}{l}\text { “去你妈的!”拉塞特 } \\
\text { 愤怒地说道 }\end{array}$ \\
\hline
\end{tabular}

The swearwords in Table 2 are all in independent pattern. They are interjections in each sentence, which, if deleted, will bring no change to the original sentence structure.

Among the four categories, independent-patterned swearwords constitute the simplest unit but cast the most powerful effect. When people have the strongest emotions, they tend to say least, but the least speech will in return produce the strongest effect.

Such strong emotions are not confined to negative feelings like anger or annoyance, but can also apply to positive ones like surprise or excitement. In Table 2, the former two examples, "Holy shit" and "Holy Christ", are exclaimed with positive sentiments.

For example, Example 1 was sworn by both Steve and Woz when they finally found the journal after great effort. In fact, in terms of character, compared to the straightforward, emotional or temperamental, rebellious and aggressive Steve Jobs, Woz is quite reserved and obedient. This "Holy shit" completely shows how excited they felt in that situation as well as their pursuit or even desire of a perfect technical feat as this journal they found could answer their doubts and finally led to their later success in Blue Box.

In terms of subject of the swearwords, "Holy" is related to religion or God, and "shit" to excrement. "Shit" is equivalent to “放屁” or “吃屎” in semantic meaning, but the latter is often used to express negative emotions in Chinese, such as disagreement or despise, while "Holy shit" in this situation is regarded as an exclamation, an expression of surprise. If "shit" is translated semantically, target readers of the translated swearwords, from a different culture, will react differently, and thus have a different idea of the matter being described and the people involved. Therefore, this swearword should be handled with the communicative approach, which is what the translator did by using “天哪”.

In Example 4, Lasseter was normally quite polite, decent, calm or reserved without the habit of swearing. However, "Fuck you" is quite a strong swearword in English. With such a strong swearing from such a decent man, readers can imagine how outrageous Lasseter was when he found himself cheated.

In terms of subject, "Fuck you" is related to sexuality. The translation “去你妈的” provide target readers with a similar experience with original readers of "fuck you". They both render the strong emotion of anger and the translation in this sense has achieved the closest effect to that of the original text.

\subsubsection{Reference Pattern}

Reference pattern, also known as metaphor/simile pattern, is in fact using the swearwords (like "shit", "shithead", "bozo") to refer to something or somebody for an insult or humiliation. In Halliday's theory, this is a relation clause with attributive or equative pattern (Halliday, 2007, p. 185). Below is a detailed analysis of the reference-patterned swearwords in Steve Jobs. 
Table 3. Reference-patterned swearwords in Steve Jobs

\begin{tabular}{|c|c|c|c|c|c|}
\hline Order & Swearword & Subject & Swearer & Chapter \& Context & Translation \\
\hline 5 & $\begin{array}{l}\text { Jobs stormed into a meeting } \\
\text { and started shouting that they } \\
\text { were "fucking dickless } \\
\text { assholes." }\end{array}$ & $\begin{array}{l}\text { Organs or } \\
\text { sexuality }\end{array}$ & Jobs & $\begin{array}{l}\text { 【4】 He humiliated the staff } \\
\text { of VSLI for their delayed } \\
\text { delivery of the chips. }\end{array}$ & $\begin{array}{l}\text { 乔布斯在会议上大发雷霆, } \\
\text { 大骂他们是”没有生殖器的 } \\
\text { 混蛋” }\end{array}$ \\
\hline 6 & That design looks like shit. & excrement & Jobs & $\begin{array}{l}\text { 【6】 He commented on the } \\
\text { designs. }\end{array}$ & $\begin{array}{l}\text { 那个设计看起来就是一坨 } \\
\text { 狗屎 }\end{array}$ \\
\hline 7 & Let's stop this bullshit! & Excrement & Jobs & $\begin{array}{l}\text { 【 } 8 \text { 】 He scolded the engineer } \\
\text { about the display of } \\
\text { word-processing programs. }\end{array}$ & 别说这狗屁玩意儿! \\
\hline 8 & $\begin{array}{l}\text { People were either } \\
\text { "enlightened" or "an asshole." } \\
\text { Their work was either "the } \\
\text { best" or "totally shitty." }\end{array}$ & $\begin{array}{l}\text { Organs }+ \\
\text { excrement }\end{array}$ & Jobs & $\begin{array}{l}\text { 【10】 Jobs referred to } \\
\text { different people. }\end{array}$ & $\begin{array}{l}\text { 人要么就是"受到过启示 } \\
\text { 的”, 要么就是"饭桶”; 人 } \\
\text { 的工作成果要么就是"最棒 } \\
\text { 的”, 要么就是"完全的垃圾” }\end{array}$ \\
\hline
\end{tabular}

In this category, the swearwords are mostly nouns as objects and function as vehicles in metaphors, such as those in Example 5, 7 and 8 of Table 3. In Example 6, the swearword "shit" itself serves as a vehicle in a simile. Among the four categories, reference pattern ranks the second in degree of swearing.

In Example 5, "fucking dickless assholes" is what Jobs said when scolding the staff for their mistake. It is related to organs or sexuality in subject, thus a very strong and direct one. However, its translated version, “没有生殖器 的混蛋” is quite disappointing. Though with a footnote saying “原文是 fucking dickless assholes, 缩写就是 FDA", this translated version still sound awkward as no one will swear like that in Chinese.

In Example 6, "That design looks like shit" is Jobs's comment on the design of his colleague. This "shit", referring to the design, is a strong insult. In terms of subject, it is related to excrement, which has its Chinese equivalent “狗屎”. The translated version “一坨狗屎” is fine as it produces both a semantic and communicative equivalent, preserving the original meaning of excrement as well as its communicative effect as an insult or criticism.

In fact, reference-patterned swearwords do not just perform as an expression of emotions of the swearers, but more so as a description of their ideas towards the reference objects. As a result, it is more an objective statement, whose original meaning should better be preserved, making semantic translation the preferred strategy. Communicative translation is used only when there is no equivalent in the target language and culture.

\subsubsection{Insertion Pattern}

Insertion pattern means that a swearword serves as an insertion in a sentence. In an insertion pattern, the swearword is usually an adverb or adjective as an intensifier of the adjective or noun it describes. For example, in "pretty damn smart", the swearword "damn" is an intensifier of the adjective "smart" to make it stronger in emotion. Because of this, this pattern produces quite a mild swearing effect, far weaker than the previous two categories.

Table 4. Insertion-patterned swearwords in Steve Jobs

\begin{tabular}{|c|c|c|c|c|c|}
\hline Order & Swearword & Subject & Swearer & Chapter \& Context & Translation \\
\hline 9 & $\begin{array}{l}\text { I had always thought he } \\
\text { was pretty damn smart. }\end{array}$ & $\begin{array}{l}\text { Religion or } \\
\text { god }\end{array}$ & Jobs & 【1】 He described his father. & $\begin{array}{l}\text { 以前我一直认为他特别聪 } \\
\text { 明 }\end{array}$ \\
\hline 10 & $\begin{array}{l}\text { He would stare into their } \\
\text { fucking eyeballs. }\end{array}$ & Sexuality & Friedland & $\begin{array}{l}\text { 【3】He described Jobs' irrational } \\
\text { passion. }\end{array}$ & $\begin{array}{l}\text { 他会一直注视着对方的眼 } \\
\text { 球 }\end{array}$ \\
\hline 11 & $\begin{array}{l}\text { This guy's a goddamn } \\
\text { hippie with b.o. }\end{array}$ & $\begin{array}{l}\text { Religion or } \\
\text { god }\end{array}$ & $\begin{array}{l}\text { Don } \\
\text { Lang }\end{array}$ & 【4】 He described Jobs. & $\begin{array}{l}\text { 这家伙是个该死的有体臭 } \\
\text { 的嬉皮士 }\end{array}$ \\
\hline 12 & $\begin{array}{l}\text { What the hell is he doing } \\
\text { in any of this } \\
\text { conversation?" }\end{array}$ & $\begin{array}{l}\text { Religion or } \\
\text { god }\end{array}$ & Amelio & $\begin{array}{l}\text { 【24】 He was angry about Jobs } \\
\text { getting into the discussion about } \\
\text { his position in the company. }\end{array}$ & $\begin{array}{l}\text { 他到底为什么会参与这样 } \\
\text { 的讨论 }\end{array}$ \\
\hline
\end{tabular}

One common feature of these swearwords is that the focus of the sentence is not them but the adjectives or nouns they describe. As a result, semantic translation seems not suitable.

For example, it is quite difficult to translate "fucking" in Example 10 by using the semantic approach. In terms 
of subject, "fucking" belongs to sexuality, which translated into Chinese will be “操”. However, it makes no sense to combine such a Chinese swearword with the rest of the sentence. Moreover, considering Friedland's neutral attitude here as well as the translation difficulty, the only method is perhaps to lower the swearing degree or even remove it.

Otherwise, some strange sentence will come out, like “该死的有体臭的嬉皮士” in Example 11, as a result of semantic translation to preserve both sentence structure and meaning. In this example, "Goddamn" belongs to religious subject, with no swearword equivalent in Chinese. So, in translation, there is a need to change it to another subject. “该死的” would be a good choice. However, the sentence structure sounds unspontaneous to the Chinese ears.

To translate insertion-patterned swearwords, it is difficult to maintain the original meaning or structure, making semantic translation inappropriate or even impossible. In this case, solutions can be found through lowering or removing the swearing degree or reforming the original structure. Thus, communicative translation is the preferred strategy.

\subsubsection{Replacement Pattern}

Replacement pattern means that the swearword replaces the original word in a phrase or sentence. That is to say, the original sentence or phrase is not swearing, and the swearword added to replace a certain word is just an intensifier of the tone instead of performing its semantic meaning. For example, "shit" in "you don't deserve shit" does not really mean its dictionary meaning: excrement, but is just an intensifier.

Table 5. Replacement-patterned swearwords in Steve Jobs

\begin{tabular}{|c|c|c|c|c|c|}
\hline Order & Swearword & Subject & Swearer & Chapter \& Context & Translation \\
\hline 13 & You don't deserve shit & Excrement & Jerry Woz & $\begin{array}{l}\text { 【6】 He was not satisfied with the } \\
\text { capital distribution by Jobs. }\end{array}$ & 你不配得到这么多 \\
\hline 14 & $\begin{array}{l}\text { Steve, I don't give a shit } \\
\text { about Apple }\end{array}$ & Excrement & $\begin{array}{l}\text { Andy } \\
\text { Glove }\end{array}$ & $\begin{array}{l}\text { 【24】 He interrupted when Jobs } \\
\text { talked about the Apple situation. }\end{array}$ & $\begin{array}{l}\text { 史蒂夫, 我才不在乎苹果 } \\
\text { 会怎么样 }\end{array}$ \\
\hline 15 & $\begin{array}{l}\text { He'll fuck the people I } \\
\text { brought into Apple. }\end{array}$ & Sexuality & Jobs & $\begin{array}{l}\text { 【24】 He assumed what Gil would } \\
\text { do to his fellows }\end{array}$ & $\begin{array}{l}\text { 而且还会把我带进苹果的 } \\
\text { 那些人都干掉 }\end{array}$ \\
\hline 16 & $\begin{array}{l}\text { It was fucked up by } \\
\text { mismanagement. }\end{array}$ & Sexuality & Jobs & $\begin{array}{l}\text { 【25】He talked about the project of } \\
\text { Apple }\end{array}$ & 因为管理不善搞砸了 \\
\hline
\end{tabular}

Similar to insertion pattern, replacement pattern produces a very weak swearing effect, so a removal or lowering of swearing can be considered. If replacement-patterned swearwords are translated semantically, the sentences will make no sense. For instance, in Example 13, if "shit" in "You don't deserve shit" is translated semantically, it would become “你不配得到狗屎”. It would be confusing or even incomprehensible to Chinese readers. Also in Example 15, "I don't give a shit about Apple", what on earth does it mean by the semantic translation of “不 给苹果一堆狗屎”? Another example is “fuck" in Example 15. "Fuck" means a sexual activity. If such a semantic meaning is translated, Chinese readers will be shocked when they read “而且还会和我带进苹果的那 些人都发生性关系”. Therefore, “fuck”, here translated into “干掉”, is a communicative approach. It serves as a pun, which preserves the sexual element and at the same time the substantial meaning of "beat" or "fire".

Generally, replacement-patterned swearwords do not perform their semantic meanings. If the semantic approach is adopted on such texts, the translation will be unreadable or incomprehensible. Therefore, translators should figure out what these words really mean, try to analyze emotions of the swearers and then add independent swearwords to express such emotions. In order words, communicative translation is more appropriate for this category.

\section{Conclusion}

To conclude, in swearword translation, a lot of elements, such as character of swearer, context, language habit of either culture and so on, should be taken into account before the translator decides which translation method to apply. Based on Peter Newmark's communicative and semantic approach to translation, among the four categories of swearwords in Steve Jobs, independent-patterned, insertion-patterned and replacement-patterned swearwords should be generally translated with the communicative approach while reference-patterned ones predominantly via the semantic approach.

Most people argue that translation of biography should be author-oriented rather than reader-oriented. However, this research proves that reader-oriented translation is a better approach. The aim of a biography is to let readers 
know what the character has experienced in his life, and what personalities of the character have been revealed from such experiences. In this sense, it is not just about information but also about feelings, i.e., how readers feel about this character. As a result, the speech of the character should produce an equivalent effect on the target readers. Only in this way will the target readers feel the same towards this character as the original readers do. Swearwords, as a kind of speech with the strongest emotions, should also be handled in the same manner.

\section{Acknowledgements}

This research is supported by the Guangdong Provincial Innovation Research Team Project: Pragmatic Culture and Identity Construction Studies (Project No. 2018WCXTD002).

\section{References}

Chen, Y. (2011). On the application of "coarse words" in contemporary Chinese literature. Success (education version), 11, 278-279.

Golan, J. (2006). Swearwords in translation. M.A. thesis of Masaryk University, Czech Republic.

Gu, C. (2010). A cultural analysis of curse word translation between Chinese and English. M.A. thesis of Shanghai International Studies University, China.

Halliday, M. A. K. (2007). On Grammar. Beijing: Peking University Press.

Hoffmann, C. (Eds.). (1996). Language, Culture and Communication in Contemporary Europe. London: WBC Book Manufacturers Ltd.

Huang, R. (2009). How to deal with dirty words in literary works. Anhui Literature, 8, 337-338.

Ma, B. (1996). Application of dirty words in literary works. Seeking Truth, 6, 31, 78-81.

Montagu, A. (2001). The Anatomy of Swearing. Pennsylvania: University of Pennsylvania Press.

Newmark, P. (2001). Approaches to Translation. Shanghai: Shanghai Foreign Language Education Press.

Wajnryb, R. (2004). Language Most Foul. Adelaide: Griffin Press.

Wu, C. (1987). Swearwords and literary language. Gansu Social Science, 1, 59-65.

\section{Copyrights}

Copyright for this article is retained by the author, with first publication rights granted to the journal.

This is an open-access article distributed under the terms and conditions of the Creative Commons Attribution license (http://creativecommons.org/licenses/by/4.0/). 